\title{
Monitoring of landslides in the Brda river valley in Koronowo (Polish Lowlands)
}

\author{
Lesław Zabuski • Waldemar Świdziński • \\ Marek Kulczykowski • Teresa Mrozek • \\ Izabela Laskowicz
}

Received: 29 April 2014 / Accepted: 6 January 2015/Published online: 14 January 2015

(C) The Author(s) 2015. This article is published with open access at Springerlink.com

\begin{abstract}
The paper discusses landslides investigated in a Brda river valley in the region of the town Koronowo near Bydgoszcz (Kujawsko-Pomorskie Voivodeship) in the Polish Lowlands. Due to morphologic and geologic setting the area is prone to slope instability. Out of 32 identified landslides, 9 were selected for detailed examination. To register a nature and rate of failures a complex monitoring system was installed on slopes where the selected landslides resulted in damages to municipal infrastructure. The system was facilitated with inclinometers and piezometers, supported by a network of GPS-RTK geodetic benchmarks as well as with a recording station. The performed examination revealed that the most unfavourable arrangement of the layers is, when under a non-cohesive soil lies a cohesive impermeable layer. The landslides are rather shallow ones (except for two incidents) with slow rate of displacement. The landslide-triggering factor is water originating from precipitation and snow melting. Influence of water was especially significant in early spring 2011 , due to
\end{abstract}

\footnotetext{
L. Zabuski · W. Świdziński · M. Kulczykowski ( $₫)$

Institute of Hydro-Engineering, IBW PAN,

ul. Kościerska 7, 80-328 Gdańsk, Poland

e-mail: marek@ibwpan.gda.pl

L. Zabuski

e-mail: lechu@ibwpan.gda.pl

W. Świdziński

e-mail: waldek@ibwpan.gda.pl

T. Mrozek · I. Laskowicz

Polish Geological Institute-National Research Institute,

Carpathian Branch in Cracow, ul. Skrzatów 1,

31-560 Kraków, Poland

e-mail: tmro@pgi.gov.pl

I. Laskowicz

e-mail: ilas@pgi.gov.pl
}

the combined effect of snow melting and infiltration of thawing water originating from the former, as well as exceptionally high rainfalls. The influence of hydrologic conditions on slope deformations is complex. There is a significant time lag between a movement initiation and unfavourable hydrometeorological conditions. That is exemplified with the landslide that was initiated in February-March 2011 in consequence of atmospheric conditions of November-December 2010. The results formed the background for inventing engineering treatment measures aiming at current remedial stabilisation of slopes and mitigation of possible landsliding in the future.

Keywords Landslide - Monitoring system .

Displacement · Polish lowlands

\section{Introduction}

In recent years, landslides in Poland have been generating increasing problems of economic and social nature, especially in areas of high-density housing and developed infrastructure. Over the last decade many new landslides have occurred and many old ones recurred because of unfavourable climatic changes. More than $90 \%$ of all Polish landslides occur in the Carpathians, where they have become noticeably more frequent over the last few years (Chowaniec and Wójcik 2012; Zabuski et al. 2009; Bober 1984; Margielewski 2006; Wójcik et al. 2006). Although smaller, compared with those in mountainous areas, landslides also develop in lower relief regions (e.g. Ostaficzuk 1999)—cliff parts of the Baltic coast (Subotowicz 2001, 2002; Tejchman et al. 1995) or moraine highlands and large river valleys, where undulated landscape was formed during the North-Polish Glaciations (Mojski 2005). A 
region where mass movements caused serious damages to urban infrastructure in the past and where a high risk of further damages exists is the Brda river valley in Koronowo near Bydgoszcz (Fig. 1).
Investigations of landslides in this region were initiated in July 2009 and performed until July 2012 (i.e. for 3 years). Their main goal was to describe the current processes of slope deformation and to determine causal
Fig. 1 Study area in Koronowo with the location of the investigated and monitored landslides indicated

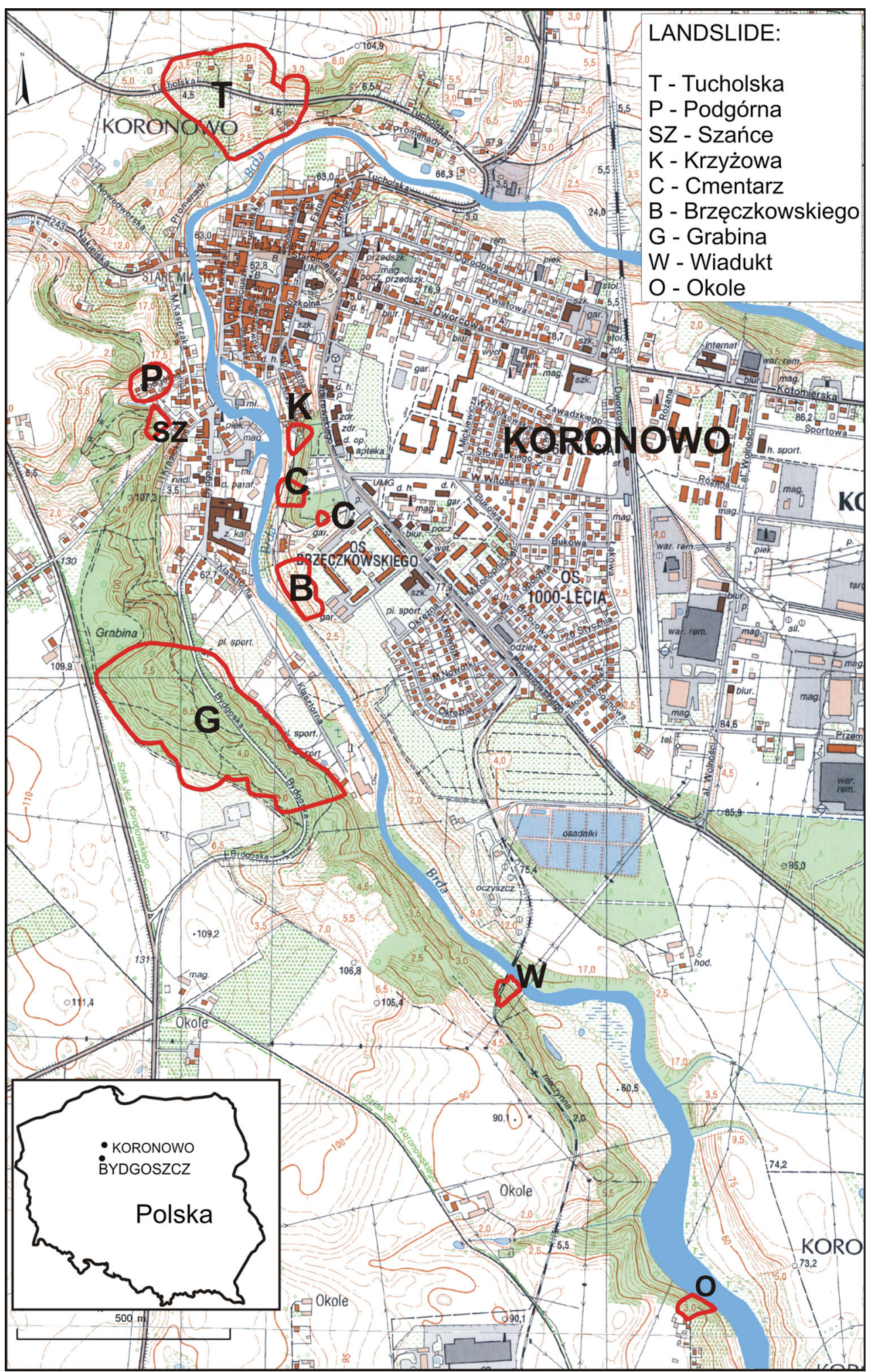


relationships, i.e. to evaluate the influence of passive and active factors and phenomena on landslide development (Zabuski et al. 2012). On the basis of geological and geomorphological investigations as well as suggestions from the local administration, nine test slopes were selected because of their high susceptibility to landslides and/or because objects vulnerable to landslide deformations were settled on these slopes or in their immediate vicinity.

A substantial part of the research programme was devoted to the monitoring of deformations and hydrogeological conditions of the test slopes. It was carried out by the system, consisting of geodetic benchmarks and inclinometers as well as piezometers. Additionally, a meteorological station was set up to measure precipitation depth and air temperature. It should be recognised that the monitoring system framework is traditional, in comparison to the complex, sometimes real-time systems, based on the photogrammetry and remote sensing (e.g. Dunnicliff 1993; Wieczorek and Snyder 2009; ClimChAlp 2008). However, its construction and arrangement is properly adjusted to the conditions of the site, with taking into account financial limitations as well.

This paper presents the geology and geomorphology of the region and of individual test slopes, geotechnical properties of the soil medium and most important, the monitoring system and measurement results. The results of the investigations are used by the local administration in Koronowo to prevent or reduce the negative effects of mass movements and to make the town safer. They are nowadays utilised by town administration to the preparation of the engineering designs, aimed at stabilising the landslides and repairing the damaged objects.

\section{Description of the study area and the test slopes}

Koronowo is a small town at the Brda river, ca. $20 \mathrm{~km} \mathrm{NW}$ of Bydgoszcz in a macro-region of the South Pomeranian Lakeland (Fig. 1). It is situated on the border between the Krajenska Upland and the Brda River Valley. The river flows generally due south, forming a bend, surrounding Koronowo from the west.

The relief pattern in the region is related to NorthPolish Glaciations, and especially to ice-sheet retreat, which left behind moraine uplands, a trough valley, being effect of erosion by proglacial water, and outwash. In effect, a morphologic threshold is noticeable in physiography of the Koronowo surroundings. In the studied area, the western valley-side of the meandering Brda river is steep. Here, the highest hills exceed $105 \mathrm{~m}$ a.s.l. and protrude ca. $47 \mathrm{~m}$ above the river level (a.r.1.). A lower, gentler face with adjacent broader terrace forms the eastern bank. The altitudes to the east of the Brda river are ca. $70-85 \mathrm{~m}$ a.s.l. and rise $20-30 \mathrm{~m}$ a.r.l. In general, slope inclinations range is $5^{\circ}-15^{\circ}$. The undulated upland is built of a thick glacial till and fluvioglacial sands, overlying (Pliocene) clays and mud with brown coal in places. The bottom of the Brda valley is filled with fluvial (varigrained) sands of flood and overflood terraces. The Brda valley-sides were remodelled by mass movements already in Pleistocene (Mojski 2005).

The average annual precipitation in the region of Koronowo amounts to $500-600 \mathrm{~mm}$. The mean annual temperature is $7.6^{\circ} \mathrm{C}$; the coldest month is January $\left(-2.8^{\circ} \mathrm{C}\right)$, but negative temperatures can be observed from November. The warmest month is July $\left(17.8^{\circ} \mathrm{C}\right)$. The mean annual precipitation in recent years has increased from $554 \mathrm{~mm}$ in the years $1955-1981$ to $727 \mathrm{~mm}$ in 2004-2011. It should be noticed that year 2010 was extreme: annual precipitation was as high as $977 \mathrm{~mm}$ with a total of winter months (November and December) reaching $236 \mathrm{~mm}$. Snow cover in the region of Koronowo is usually observed from December till March, when it starts to melt, while its thickness varies from 6 to $25 \mathrm{~cm}$ (Lorenc 2005; Kożuchowski 2011). In winter season 2010/2011, mid-winter thawing was observed.

The study area was about $15 \mathrm{~km}^{2}$ and comprised the town of Koronowo and its rural surroundings, where the farmland $(43 \%)$ is important land use, but forest and bushes cover 12 and $14 \%$, respectively. On the basis of geological field mapping, topographic reconnaissance, and aerial photo interpretation, 32 landslides were identified. Total surface area of all landslides equals ca. 45 ha, and average area of an individual landslide is equal 0.14 ha. The landslides were classified according to the combined schemes of Varnes (1978) and Cruden and Varnes (1996). Compound rotational-translational landslides predominate (17 landslides), some are classified as translational (13 landslides) and only two are typically rotational. The morphologic forms of the terrain as well as outcrops quite often indicate a roto-translational mechanism of the movement. Slip surfaces in the region of the main scarps have a rotational shape and are approximately linear in the lower parts. It is especially noticeable in the landslides $\mathrm{W}$ and $\mathrm{O}$ (see Fig. 1). The point at which the movement has been initiated is impossible to determine unambiguously, yet it is highly probable that a progressive process occurs, which means that the phenomenon develops from the top to the toe of the slope. In the first stages of the process, cracks appear and widen in the uppermost portions of the slope, and water that infiltrates into these cracks exerts pressure on their walls, thereby weakening the soil. The total area of all landslides is $590,000 \mathrm{~m}^{2}$, including $120,000 \mathrm{~m}^{2}$ of active landslides, and the average area of an individual landslide is $14,000 \mathrm{~m}^{2}$. The area of the largest one (Grabina, G) amounts to ca. $113,000 \mathrm{~m}^{2}$, and the smallest one 
(Cmentarz1, C) has an area of ca. $600 \mathrm{~m}^{2}$. The landslides on the western valley-side of the river are generally larger and more numerous than those on the eastern side. It can be attributed to steeper gradients of the slopes, lithological pattern and erosional power of the river in the past. At present, increasing human impact, associated with urbanization, is also an important factor which might lead to slope instability.

The investigations and monitoring were performed on nine landslide slopes, which had been selected as test slopes (see Fig. 1). The main reason of the choice of these slopes was the harmfulness of the recent or potential landslide movement on the local housing and infrastructure of the town.

In the selected nine test slopes, 36 boreholes were carried out. A detailed geological mapping of borehole cores made it possible to divide the soil masses composing these slopes into four structures (Fig. 2). The soil mass of the first structure builds the slopes $\mathrm{C}, \mathrm{B}, \mathrm{P}$ and the southern part of G, where fluvioglacial varigrained sands and gravels occur. The second structure (landslide $\mathrm{K}$, the central part of $\mathrm{G}$, partially SZ, the toe of $\mathrm{O}$ ) is formed of a several-metersthick subsurface layer of cohesive soil (clay, loam), underlaid by non-cohesive sands and gravels. The structure third is composed of a several-meters-thick subsurface layer of non-cohesive soil, underlaid by plastic clays and loams (northern part of G, O, partially W and SZ). Only the landslide $\mathrm{T}$ is composed of the mass classified as structure four in which layers of different soils are visible, such as sand, clay, peat, and brown coal.

The hydrogeological conditions are generally favourable for stability of the slopes. In most of the boreholes, water does not appear. Very high levels of the ground water (less than $1 \mathrm{~m}$ below the ground surface) are observed in boreholes in the landslide $\mathrm{T}$. The water table is also present at a depth of 1-2 $\mathrm{m}$ in the upper regions of the landslide $\mathrm{O}$ and at $5 \mathrm{~m}$ near the main scarp of SZ. The results of piezometric observations show that the amplitudes of water table fluctuations are smaller than $1 \mathrm{~m}$.

\section{Monitoring}

A monitoring system was constructed to measure both the effects and the causes of mass movements. From among 36 boreholes, inclinometric casings were installed in 23 , and open-pipe piezometers in 13. The effects, i.e. displacements, were systematically measured in inclinometric boreholes once a month, on average. Moreover, geodetic measurements of 48 benchmarks were carried out twice a year, in spring and autumn. Owing to difference in accuracy of these two kinds of measurements, it is practically impossible to compare their results with any accuracy. Geodetic measurements are useful, however, in detecting the zones of higher deformation activity in places where inclinometric boreholes are not installed and in comparing deformation activity in specific landslide zones. Nevertheless, the principal information about landslide movements was provided by the results of inclinometric measurements. Inclinometric boreholes were made in different zones of the landslide, i.e. near its main scarp, in the middle, and in the toe. They were usually accompanied by piezometric boreholes for the investigation of the relationship between displacement and the groundwater table. For example, the distribution of boreholes in the slope $\mathrm{T}$ is presented in Fig. 3.
Fig. 2 Division of the soil massifs composing the slopes into structures

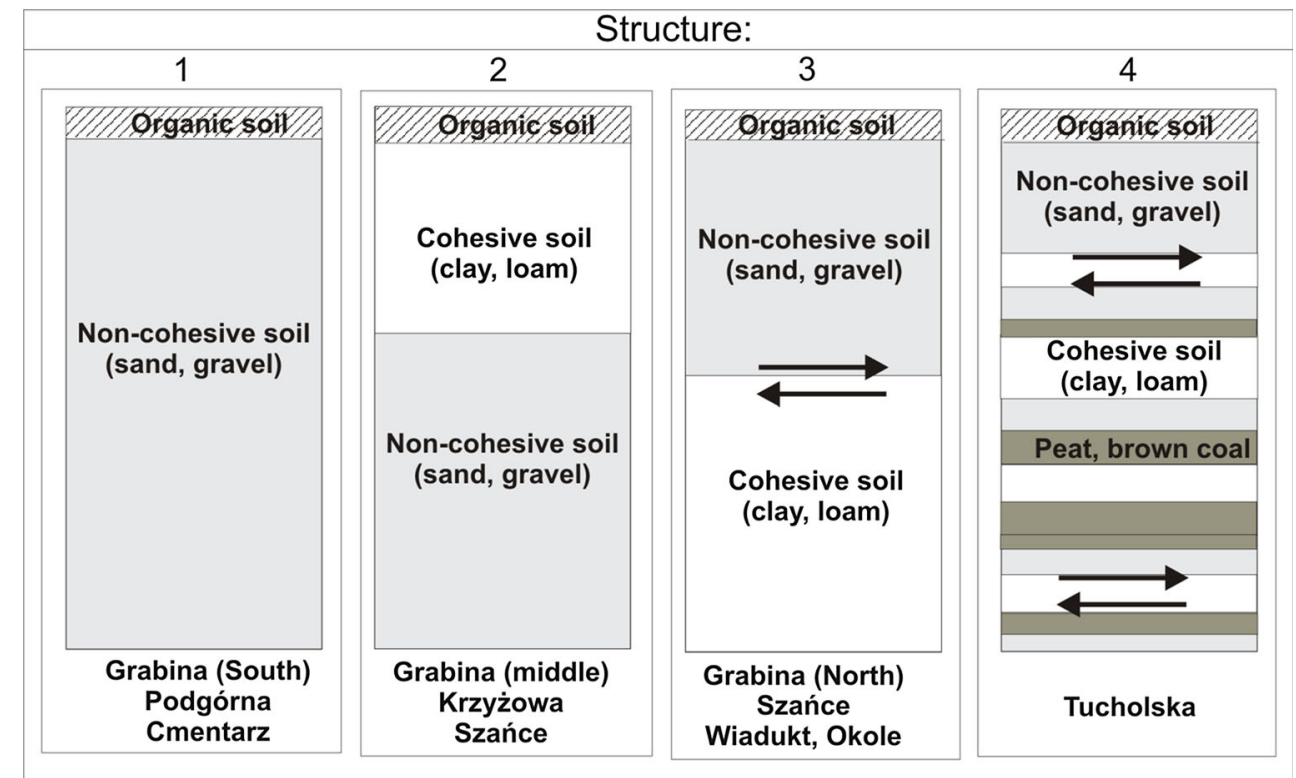




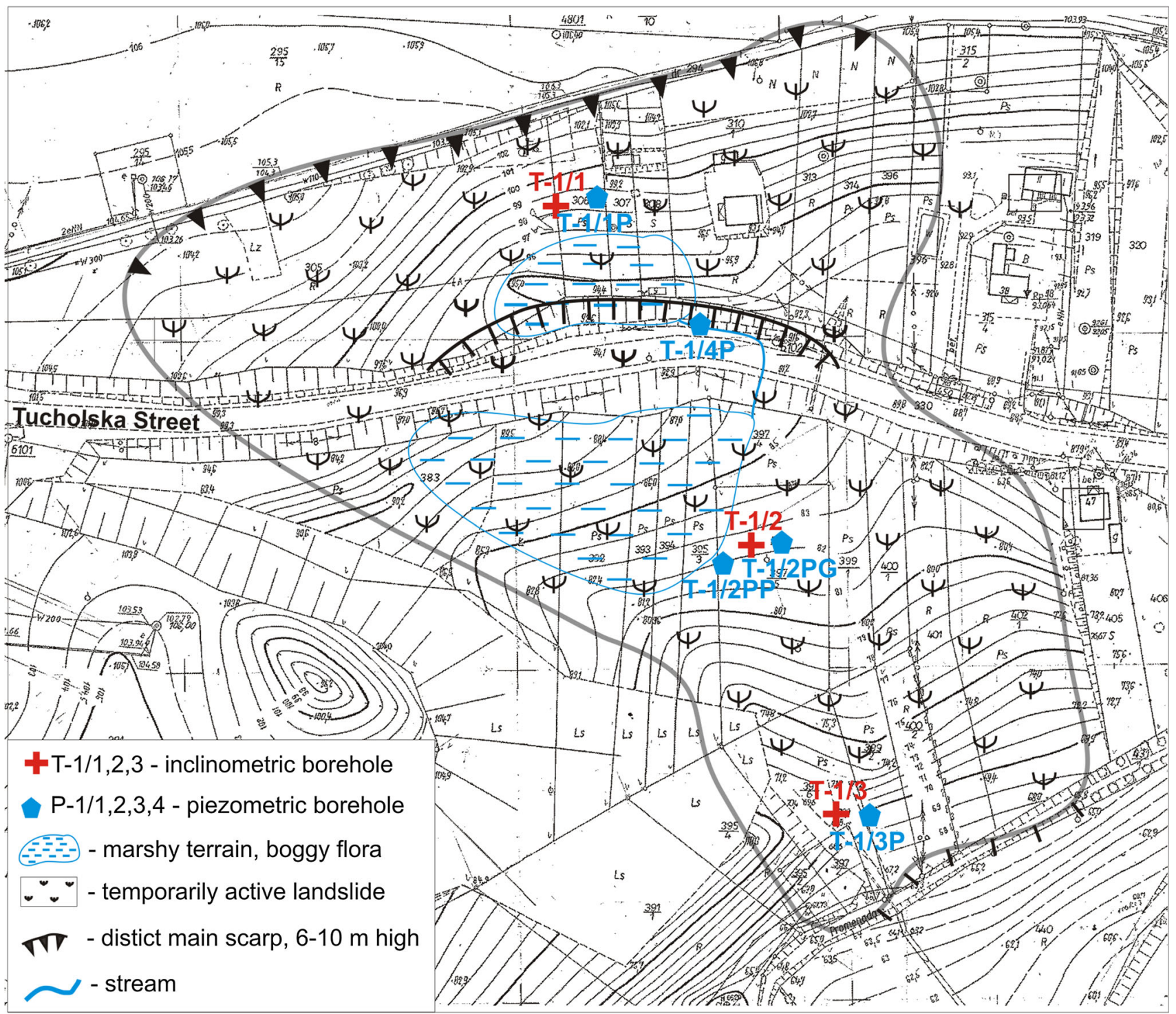

Fig. 3 Map of the landslide $\mathrm{T}$ indicating the location of inclinometric and piezometric boreholes

There are two types of inclinometric curves, showing significantly different behaviour of the slopes. Results from the boreholes proved the stability of some slopes, as the measured displacements were practically within the range of the accuracy of the measuring device. The landslides $C$, $\mathrm{K}, \mathrm{P}$, and the southern and middle parts of $\mathrm{G}$ belong to this group. It could be thus concluded that these slopes were stable during the measurement period, although some signs of former deformations are evident when the morphology of the slopes is inspected. In contrast, the boreholes in T, G (north) and SZ reveal mass movement. Figure 4 shows example results from two boreholes.

The depth of the landslides is generally small and ranges from $1.5-2.5$ to $5 \mathrm{~m}$ (Fig. $4 \mathrm{~b}$ ). One exception is the landslide T. A slip surface was identified at the depth of $15 \mathrm{~m}$ in its upper part, at $13 \mathrm{~m}$ in the middle part (Fig. 4a), and at ca.
$6 \mathrm{~m}$ in the toe region. The average displacement rate amounted to a few mm/year, and according to Varnes (1978) classification, a movement rate below $60 \mathrm{~mm} /$ year is qualified as extremely low. A relatively large displacement increment can be observed in the figures for the period between November 2010 and March 2011. Indeed, this period could be considered as critical, since catastrophic movement occurred in two cases, namely in the landslides $\mathrm{W}$ and $\mathrm{O}$. The displacement of the landslide $\mathrm{W}$ was at least $10 \mathrm{~m}$, which resulted in the damage of an old narrow-gauge railway embankment in the nearest vicinity of a bridge over the Brda river. The first cracks in the neighbourhood of the main scarp appeared in February 2011, followed by a large and rapid movement in March. Figure 5 shows the main scarp of this landslide. Similar huge deformations occurred during the same period in the landslide $\mathrm{O}$. 


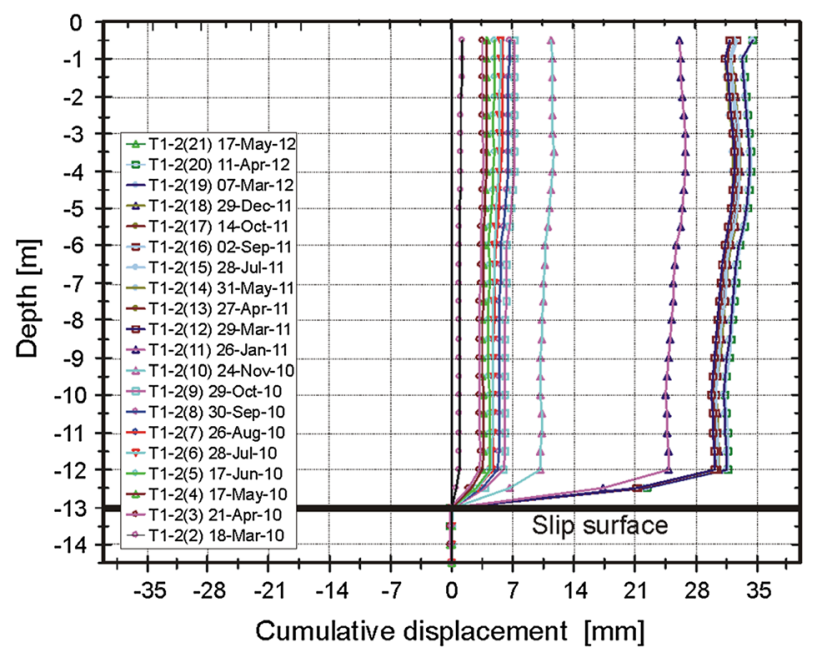

(a)

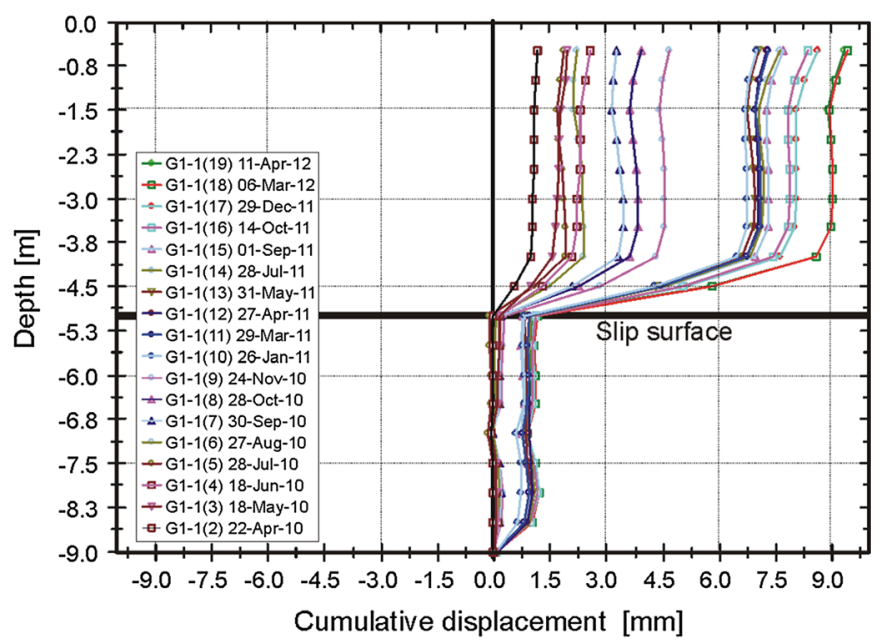

(b)

Fig. 4 Example inclinometric displacements with slip surfaces marked: a landslide T, borehole T1/2; b landslide G, borehole G-1/1

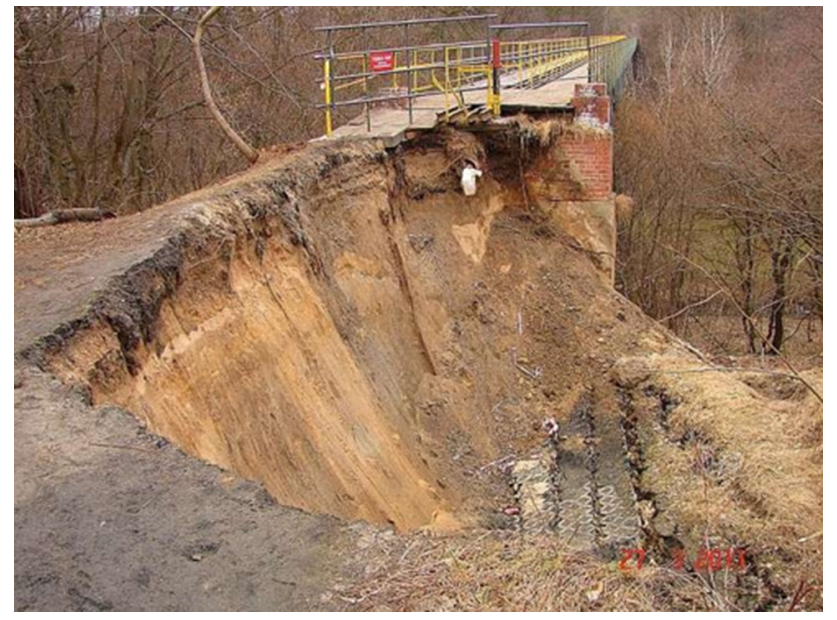

Fig. 5 Main scarp of the landslide W in March 2011

An automatic meteorological station was installed, measuring continuously precipitation and air temperature. Moreover, the annual and monthly precipitation data for the years 1955-1981 and 2004-2012 at a station located in Koronowo were taken into account. The distribution of the average annual precipitation and the sums of precipitation in November and December are shown in Fig. 6.

As shown in Fig. 6, the annual precipitation in 2010 and the sum of precipitation in November and December 2010 were, respectively, 134 and $255 \%$ of the corresponding averages for the last 34 years recorded. However, the influence of precipitation on slope behaviour appears to be a complex question, as the response of the slopes does not depend on precipitation only. The processes of evaporation and transpiration, which depend on the season of the year, should be taken into account, as well. According to Lambor (1971), the sum of annual evaporation and transpiration in the Koronowo region is about $350-400 \mathrm{~mm}$, which means that $30-50 \%$ of water from precipitation does not infiltrate into the slope. Due to physiography of the study area (biologically active terrain, sand and clay substratum, slope inclination to $15^{\circ}$ ) the surface run-off can be of an order of $10 \%$ of precipitation total (Bochenek and Gil 2007; Walków 2012). It can be added as well that following reasons substantially decreased run-off:

- daily precipitation of relative low intensity in November 2010 (20 days with daily precipitation lower than $3-4 \mathrm{~mm}$; 5 days with higher precipitation $>10 \mathrm{~mm} /$ day),

- soil cover not frozen in November yet; facilitating infiltration,

- small inclination of the slopes and old, mature landslides with many irregularities, depressions and hollows.

More precise information about water conditions inside the slope is provided by piezometric measurements. Most of the piezometric boreholes were found to be dry during the period of the investigations. Therefore the measurement programme was divided into two stages to observe water conditions over a longer period. During the first 7 months, measurements were carried out, on average, every month with a geologic whistle in all 13 boreholes. In the second stage, boreholes with permanent water table were identified, and automatic piezometers with atmospheric pressure compensation were installed in five of them ( 3 on the landslide $\mathrm{T}, 1$ on the landslide $\mathrm{SZ}$ and 1 on the landslide $\mathrm{O}$ ) to measure the groundwater level (GWL) every $2 \mathrm{~h}$. In addition, hand measurements with the use of a whistle were continued in all piezometric boreholes, and the results of both measurements were compared and verified. A 


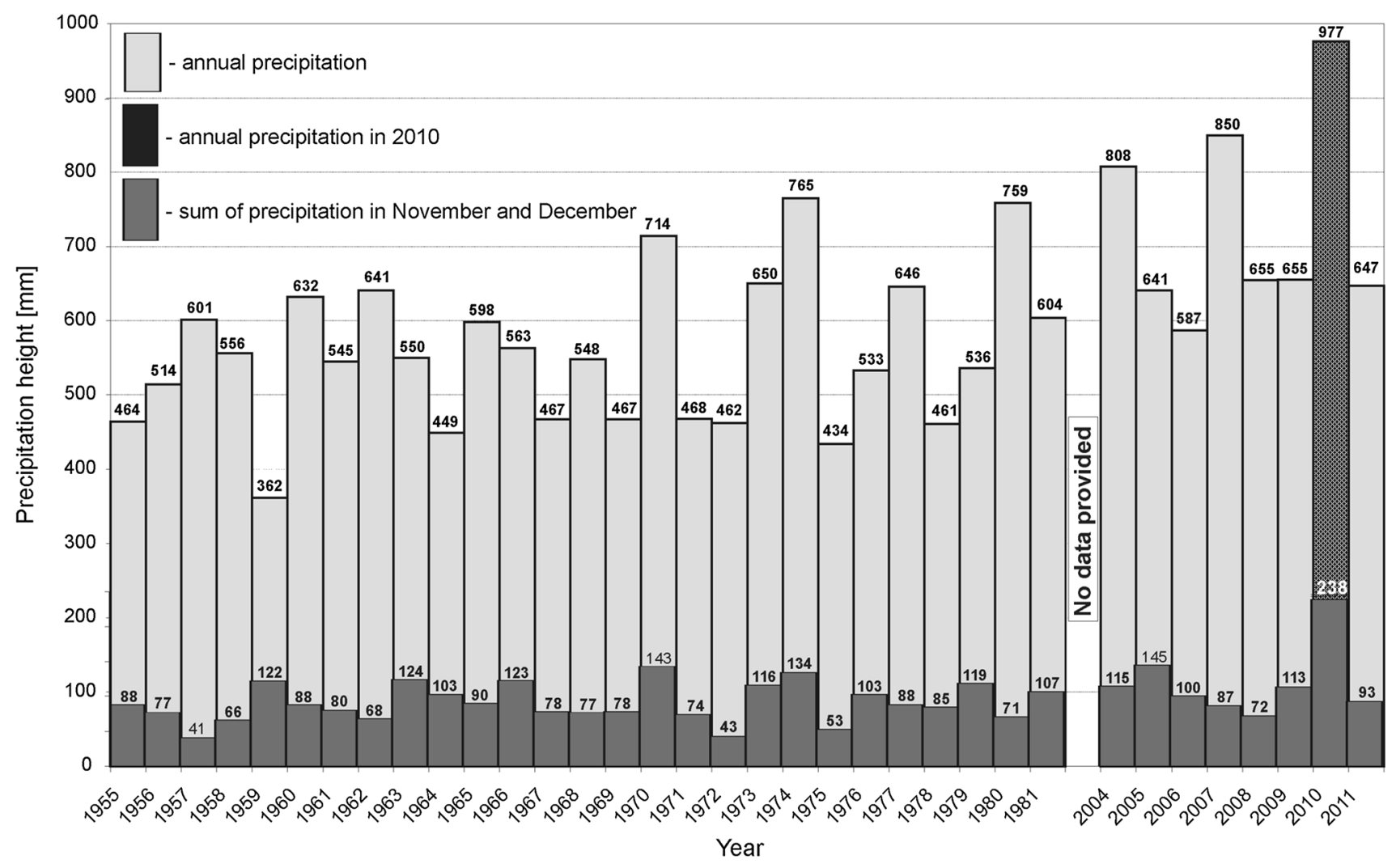

Fig. 6 Annual precipitation and sums of precipitation in November and December in the years 1955-1981 and 2004-2011

permanent GWL was observed in the landslide slope T, which was practically filled with water, as well as in some parts of the landslides SZ and O.

It should be mentioned that systematic measurements of the GWL make it possible to describe hydrogeological conditions in landslide slopes and to search for a relationship between the GWL and landslide deformations. This question will be discussed in the next chapter.

\section{Discussion on the factors influencing landslide development}

In general, it is possible to distinguish between passive and active factors influencing landslide development. The passive ones include slope morphology (inclination, aspect, elevation), vegetation cover, hydrological conditions, land use, and the lithology of the slope soil. In Koronowo, the influence of the above factors is not noticeable. One important exception is lithology. As explained in the preceding chapters, the arrangement of soil layers has a dominant influence on slope behaviour. An impermeable layer below highly permeable sand cover (structure 3; see Fig. 2) creates particularly favourable conditions for landslide development. Such an arrangement, observed in the main scarp outcrop, is presented as an example in
Fig. 7. A clear line dividing sand and clay is marked in the figure. In fact, a displacement of many meters was observed in this slope (W). Conditions favourable to sliding are also the effect of the presence of weak soils, such as peat and mud (structure 4-landslide T). The lithology of the soil massif explains the fact that most of the landslides are located on the western bank of the Brda river, where structures 3 and 4 dominate.

However, as it is commonly known, unfavourable conditions of passive nature are not sufficient for movement initiation. Additionally, a combination of active factors is necessary to trigger the movement of a landslide.

One could expect a removal of buttressing due to erosional undercutting by the Brda river to be a landslide trigger, at least in some locations. However, river erosion might be attributed mainly to slope failures observed in remote past. In 1956-1961 the Koronowo reservoir was built. Due to the dam closing the reservoir and diverting the flow to the Lateral Channel, the current of the old Brda has become significantly slower as well as the water level amplitudes have not changed and, therefore, the river influence can be neglected as a factor triggering mass movements.

As amply demonstrated by the results of this research, the main and decisive influence on landslide deformations was exerted by climatic conditions, which were particularly favourable for landslide development in 2010 and at the 
Fig. 7 Main scarp of the landslide $\mathrm{W}$ with a marked division between soil layers

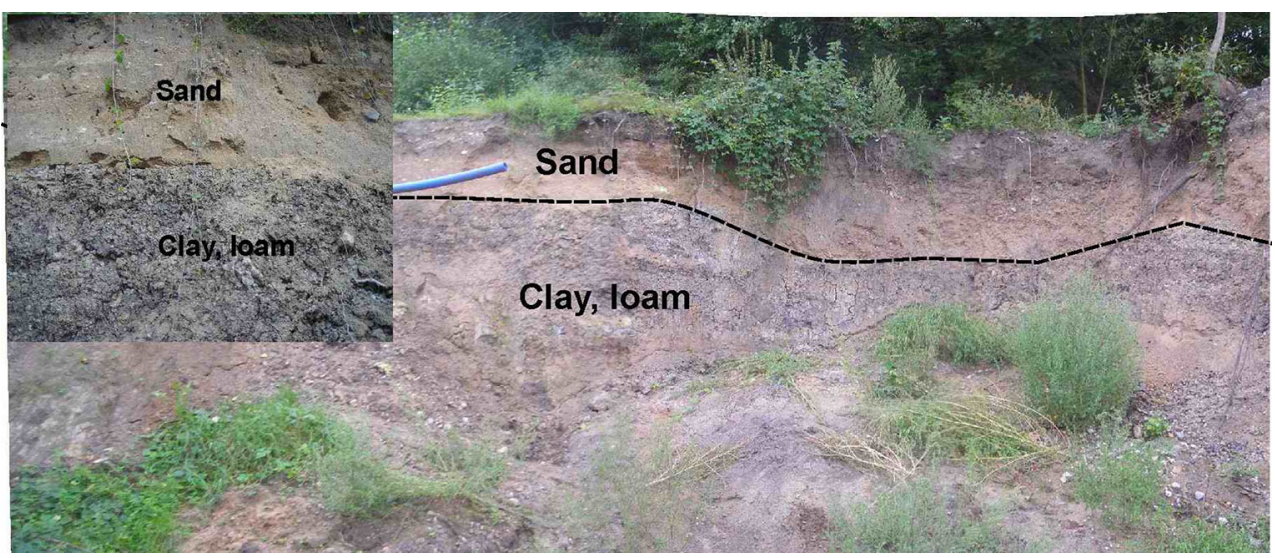

beginning of 2011, as shown in Fig. 6. Figure 8 presents three charts: the precipitation pattern, the ground water level (for the landslide T), and displacement curves (for the borehole $\mathrm{T}-1 / 2$ ).

It is seen that the displacement rate increased significantly as a consequence of unfavourable conditions of precipitation and GWL, yet the delay between their peak between December 2010 and January 2011 and the landslides of February and March 2011 requires an explanation. A detailed analysis of the curves in Fig. 9 reveals the cause of this delay.

The whole year 2010 was characterised by high precipitation, but summer evaporation and transpiration reduced its unfavourable effects, so that mass movements did not develop at that time. The decisive period for the subsequent instability phenomena began in November, i.e. about 4 months before the initiation of the landslides W and O. In this particularly extreme period November 2010February 2011, the total amount of the precipitation prior to the landslide initiation was equal to ca. $320 \mathrm{~mm}$ (236 $\mathrm{mm}$ in November-December), whereas the snow cover (when the temperature fell below zero) was equal to approximately $50 \%$ of the total precipitation.

Moreover, due to positive but low air temperature in November, evaporation and transpiration were lacking, so water infiltrated into the unfrozen slope massif. Indeed, water was retained there, but the period was too short to create high pore pressure increase in the potential slip zone.

As a result of negative temperatures in December the superficial layer of the ground froze, thus trapping the water in the slope. At the same time, intensive snowfalls took place, especially in December, producing a ca. $20 \mathrm{~cm}$ thick snow cover. A temperature rise already in January and positive temperature till mid-February (Fig. 8) resulted in so called mid-winter thawing period. It caused the snow to melt and released the water trapped in the slope. The combined effect of the presence of water from November rainfalls and December snow was a significant pore pressure increase and the weakening of the clay layer (the shear strength parameters of clay composing the slip surface in the limit equilibrium state were very low, i.e. cohesion $c=10 \mathrm{kPa}$ and the angle of internal friction $\left.\Phi=6^{\circ}\right)$. This triggered the landslides $\mathrm{W}$ and $\mathrm{O}$ as well as accelerated the displacements on other slopes (Fig. 9).

\section{Summary and conclusions}

The monitoring system consisted of devices measuring both the effects (landslide displacements) and their causes of active nature (ground water level, precipitation, temperature) which made it possible to investigate causal relationships.

However, the primary passive cause of the landslides was a specific geological structure of the slope soil mass. It was proved that the most unfavourable structure, from the lithological point of view, is the one in which an impermeable layer of cohesive soil (e.g. clay, loam) lies below permeable non-cohesive sand and gravel. The inclinometric boreholes installed in such place on landslide $\mathrm{W}$ were broken after only 3 months of measurements on the depth corresponding with sand-clay contact. Another structure prone to sliding is the one composed of weak soils, such as peat interbedded with clay. In contrast, there were no significant landslides or only small slides at very shallow depths $(0.5-1.5 \mathrm{~m})$ on slopes composed entirely of non-cohesive soils.

The only active factor that affected and triggered mass movements was rainfall and snowmelt water. The extremely unfavourable climatic situation in 2010 can be considered as very fortunate from the point of view of the researchers, as it enabled them to conduct their investigations at the time when conditions were highly favourable for landslide development.

However, a straightforward causal relationship between them and the landslides could not be easily determined. There was a significant time gap of 3-4 months between 

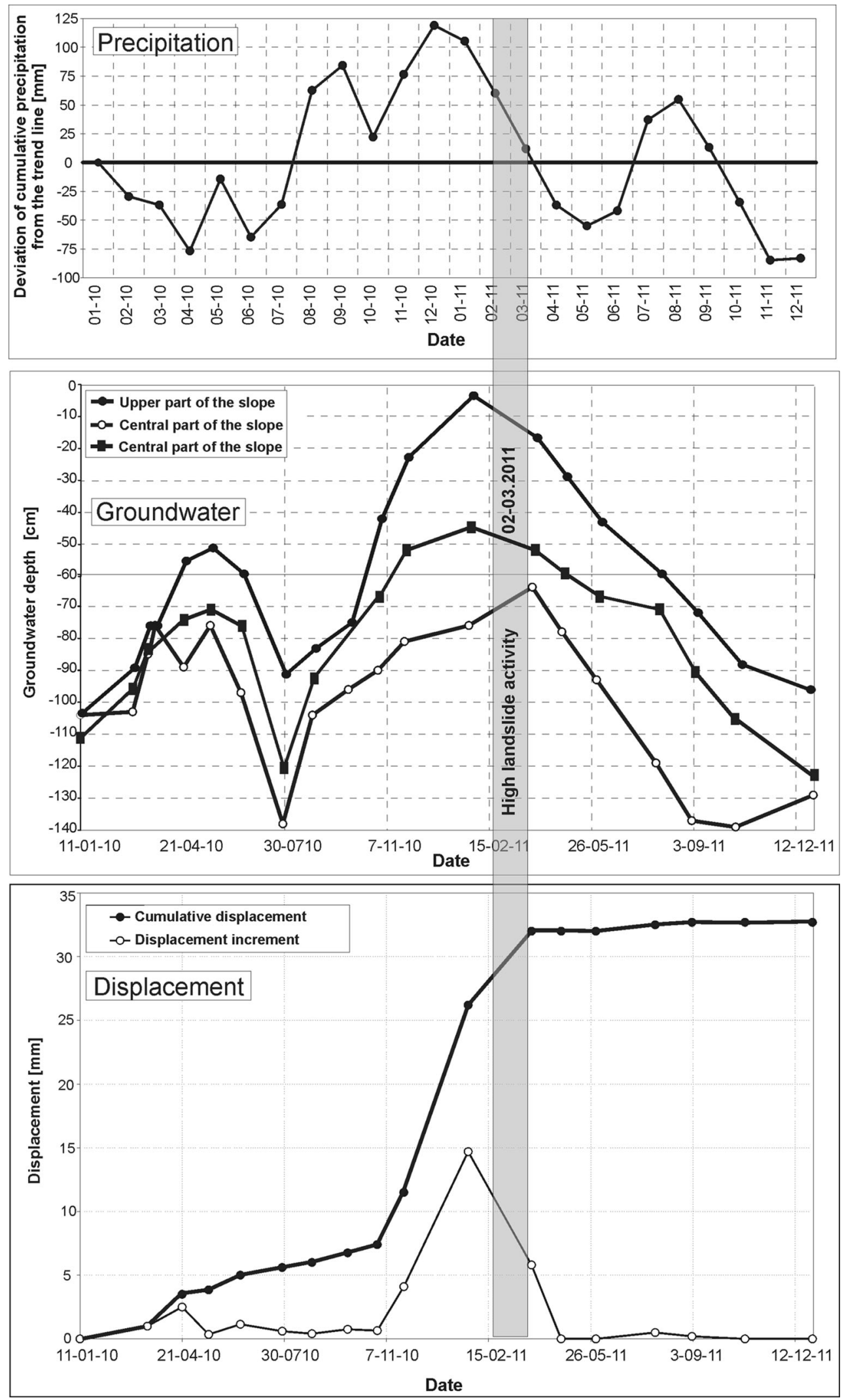

Fig. 8 Selected diagrams of precipitation, groundwater level, and displacement 


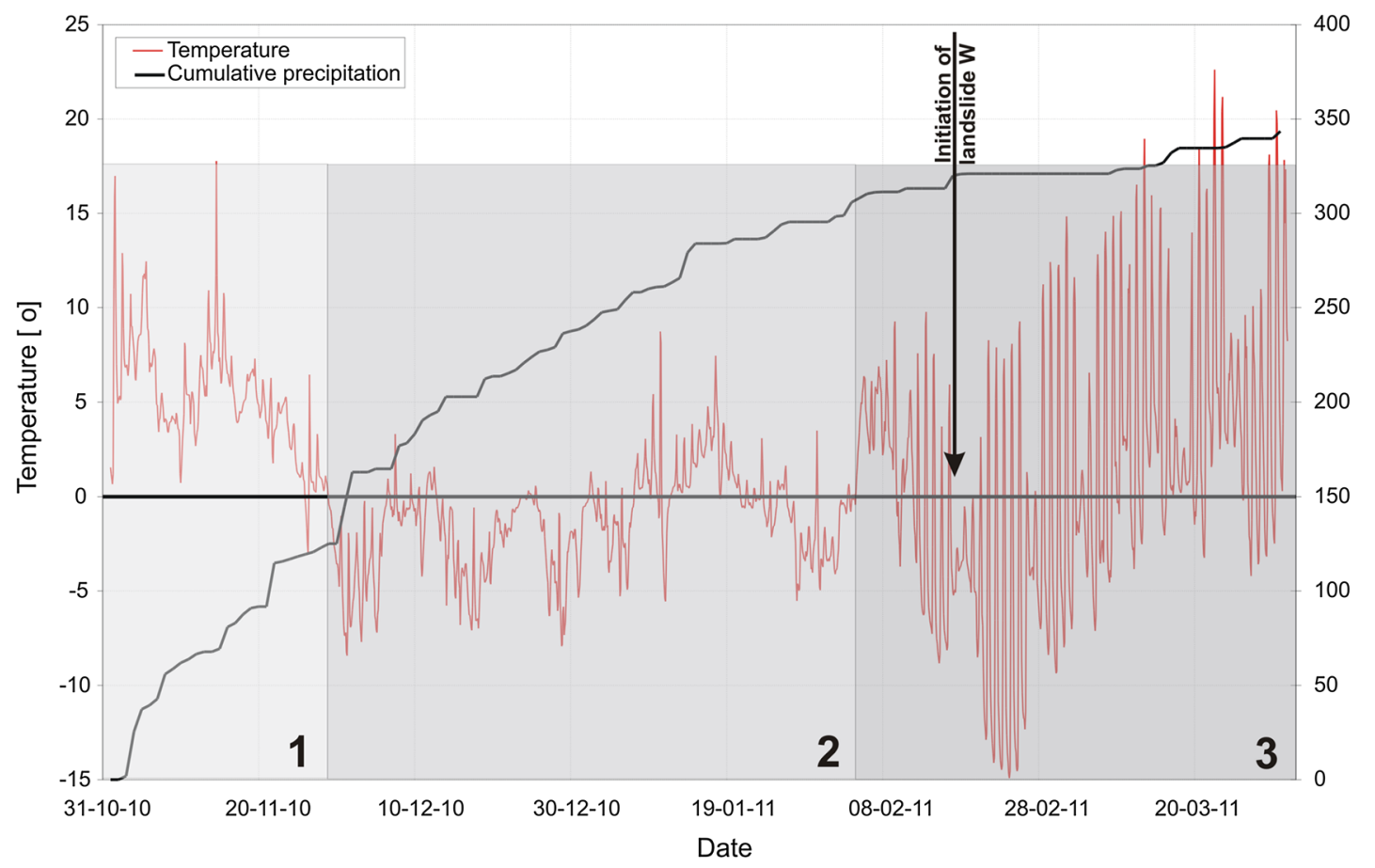

Fig. 9 Temperature and cumulative precipitation curves for the period preceding the initiation of landslides

extremely high precipitation (including rain and snow) in November and December 2010 and the subsequent mass movements, that is, the landslides $\mathrm{W}$ and $\mathrm{O}$ in February and March 2011. The cause of this delay can be explained when the temperature is taken into account. A specific combination of rain, snow, and temperature fluctuations created conditions that were highly favourable for the initiation and development of the landslides $\mathrm{W}$ and $\mathrm{O}$ and for an accelerated displacement of other landslides (e.g. the landslide T; see Fig. 8). It proves that it is very difficult or even impossible to formulate a simple relationship between landslide displacements and factors triggering these phenomena. The explanation of the causes of the landslides in the Koronowo region is therefore a matter for an expert analysis.

The present description of the phenomena occurring in soil slopes and the presentation of selected research results give an idea of slope stability problems that are observed in the selected lowland regions in Poland. It can be seen that only relatively small number of landslides develop with the high rate, and this only happens in periods of extremely unfavourable climatic conditions, as in 2010 and 2011.

Acknowledgments The work presented in this paper was supported by the National Centre for Research and Development (Grant No. 14-0008-06) titled "Opracowanie koncepcji ustabilizowania osuwisk w doline Brdy w Koronowie $\mathrm{z}$ uwzględnieniem mechanizmów deformacji zboczy i oceną ryzyka osuwiskowego" (The development of a plan for landslide stabilisation in the Brda river valley in Koronowo based on the assessment of landslide risk and slope deformation mechanisms).

Open Access This article is distributed under the terms of the Creative Commons Attribution License which permits any use, distribution, and reproduction in any medium, provided the original author(s) and the source are credited.

\section{References}

Bober L (1984) Landslide regions in Polish flysch Carpathians and their relation with geological structure (in Polish). Biul Inst Geol 340:115-162

Bochenek W, Gil E (2007) Procesy obiegu wody, erozji gleb i denudacji chemicznej w zlewni Bystrzanki. (Processes of water circulation soil erosion and chemical denudation in the Bystrzanka catchment; in Polish). Przegl. Nauk. Inżyn. Kształt. Środ. $16(2): 28-42$

Chowaniec J, Wójcik A (eds) (2012) Osuwiska województwa Małopolskiego - Atlas - Przewodnik (Landslides in Malopolskie Voivodeship-Atlas-Guidebook; in Polish). Wydawnictwo Kartograficzne Compass, Kraków

ClimChAlp (2008) Slope monitoring methods. A State of the Art Report, Strategic Interreg IIIB ClimChAlp. www.alpine-space.org

Cruden DM, Varnes DJ (1996) Landslides types and processes. In: Turner AK, Schuster R (eds) Landslides: investigations and mitigation, transportation research board, NRC Washington DC Special Report 247, pp 36-75

Dunnicliff J (1993) Geotechnical instrumentation for monitoring field performance. John Wiley \& Sons, New York

Kożuchowski K (2011) Klimat Polski. Nowe spojrzenie (Climate of Poland: a new approach; in Polish). Wydawnictwa Naukowe PWN, Warszawa 
Lambor J (1971) Hydrologia inżynierska (Engineeering hydrogeology; in Polish). Arkady, Warszawa

Lorenc H (ed) (2005) Atlas klimatu Polski (Climate of PolandAtlas; in Polish). Institute of Meteorology and Water Management, Warszawa

Margielewski W (2006) Structural control and types of movements of rock mass in anisotropic rocks: case studies in the polish flysch Carpathians. Geomorphology 77:47-68

Mojski J (2005) Ziemie Polskie w Czwartorzędzie - Zarys morfometryczny (Polish territory in quaternary-morphometric overview; in Polish). Państwowy Instytut Geologiczny, Warszawa

Ostaficzuk S (1999) Variety of landslides in Poland, and their possible dependence on neogeodynamics, In: Griffiths JS, Stokes MR, Thomas RG (eds) Landslides. Proceedings of the ninth international conference and field trip on landslides, Bristol, United Kingdom, pp 111-127, 5-16 Sept 1999

Subotowicz W (2001) Lithodynamics of Polish cliff coast (in Polish). GTN-Gdańsk, Ossolineum Office

Subotowicz W (2002) Landslide of Jastrzębia Góra cliff near "Horyzont" hotel (in Polish). In: Proceeding of fifth conference on geology and geomorphology of Southern Baltic Coast, Słupsk-Rowy

Tejchman A, Gwizdała K, Świdziński W, Brzozowski T, Krasiński A (1995) Stability and protection of Polish cliff coast (in Polish). Gdańsk Technical University, Gdańsk
Varnes DJ (1978) Slope movement types and processes. In: Schuster R, Krizek R (eds) Landslides-analysis and control, Transportation Research Board, NRC Washington, D.C., Special Report 176 , pp 12-33

Walków M (2012) Woda w mieście - wyzwanie zrównoważonego rozwoju w XXI wieku (Water in city-sustainable development challenge of 21 century; in Polish). In: Kronenberg J, Bergier T (ed) Przyroda w mieście. Usługi ekosystemów - niewykorzystany potencjał miast, Fundacja Sendzimira, Kraków 2012, ss. 91-112

Wieczorek GF, Snyder JB (2009) Monitoring slope movements. In: Young R, Norby L (eds) Geological monitoring: Boulder, Colorado, Geological Society of America, pp 245-271

Wójcik A, Mrozek T, Granoszewski W (2006) Lithological conditioning of landslides and climatic changes with examples from the Beskidy Mts., Western Carpathians, Poland. Geografia Fisica e Dinamica Quateranria 29:197-209 (special issue)

Zabuski L, Wójcik A, Gil E, Mrozek T, Rączkowski W (2009) Landslide processes in flysch massif-case study of the Kawiory landslide. Beskid Niski Mts. (Carpathians, Poland). Geol Q 53(3):317-332

Zabuski L, Świdziński W, Kulczykowski M (2012) Identification and monitoring of landslide processes in Brda river valley in Koronowo (in Polish). Inżynieria Morska i Geotechnika 6:691-700 